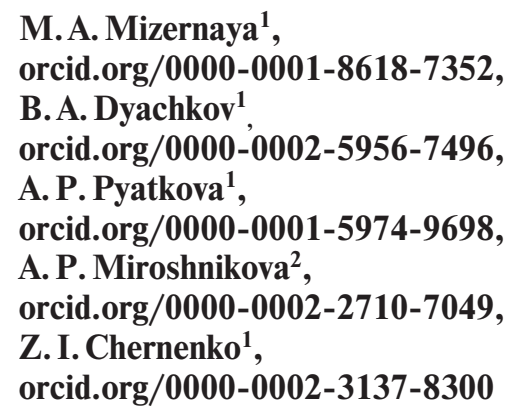

1 - D. Serikbayev East Kazakhstan Technical University, UstKamenogorsk, the Republic of Kazakhstan, e-mail: mizernaya58@bk.ru

2 - Affiliate of RSE "NE CPMRM RK" "VNIItsvetmet", Ust-Kamenogorsk, the Republic of Kazakhstan

\title{
LEADING GENETIC TYPES OF BASE METAL DEPOSITS OF RUDNY ALTAI
}

Purpose. Study on the processes contributing to the formation of pyrite-polymetallic mineralization in the Rudny Altai, development of recommendations for directions for further research.

Methodology. Analysis of literature and fund materials, field studies within known ore fields and deposits, sampling and laboratory studies: spectral analysis, studies on the chemical composition of host rocks (ISP-MS - Agilent 7500cx), study on the mineral composition of the main types of mineralization (JSM 6390LV)).

Findings. A model of pyrite-polymetallic mineralization genetically related to the Devonian basalt-andesite-rhyolite Early Hercynian riftogenic volcanism (D1e-D3fr) was developed.

Originality. The spatial confinement of a number of industrial deposits, areas of sulfide mineralization and near-ore-hydrothermally altered rocks to the areas of pinching out of inter- and sub-stratal subvolcanic porphyries of the Middle - Upper Devonian and overlying porphyrites, creating a kind of ore-magmatic systems (OMS), has been established.

Practical value. A new stage of deep geological study on the territory of the Rudny Altai and promising ore-bearing structures with the introduction of modern methods of deep geological and mineragenic mapping is recommended.

Keywords: genesis, pyrite-polymetallic ores, porphyries, ore-magmatic systems, Rudny Altai

Introduction. The Rudny Altai is known as a region where large and medium-sized non-ferrous metal deposits are concentrated. Many industrial deposits of copper, lead, zinc, gold, silver and other metals which form the large Rudnoaltai copper-polymetallic belt are located within it. This belt is divided into three metallogenic zones: Beloubinsky-Sarymsaktinsky, Rudnoaltaysky and Irtyshsky. The main deposits on the territory of Kazakhstan and Russia are concentrated in five ore regions: Leninogorsky, Zyryanovsky, Priirtyshsky, Zmeinogorsky and Rubtsovsky (Fig. 1).

Many researchers have made a great contribution to the study on the Rudny Altai geology and metallogeny (P. P. Burov, N. P. Kurek, A. K. Kayupov, P. F. Ivankin, G. N. Shcherba, V. V. Popov, B. A. Cheprasov, D. I. Gorzhevsky, G. F. Yakovlev, V.V.Avdonin, Starostin, M.G. Khisamutdinov, V.M.Chekalin, Kh.A. Bespayev, Yu. I. Demin, N. I. Stuchevsky, and others). One of the most controversial questions was the genesis of this large ore-bearing structure.

The purpose of this article is to clarify and deepen the previously identified patterns of formation of pyrite ores within the Kazakhstani part of the Rudny Altai, to form new criteria for their further search.

Three hypotheses of pyrite-polymetallic deposit genesis were considered in the history of the geological study on the Rudny Altai: intrusive, effusive hypotheses as well as volcanogenic hypothesis, which is taken as a basis in this article [1].

According to this theory, the pyrite-polymetallic ores were formed earlier than the main Saurian $\left(\mathrm{C}_{1}\right)$ folding phase, before multiple-act schistening, crushing of rocks and the formation of granitoid intrusions of the Zmeinogorsk complex and their derivatives. The main source of ore-bearing solutions involved differentiated deep basaltoid magma chambers; ores were formed synchronously with the formation of Devonian volcanic-sedimentary deposits and fluidporphyry complexes.

Proponents of this theory pointed at clear signs of submarine volcanic-sedimentary or hydrothermal-sedimentary ore

(C) Mizernaya M.A., Dyachkov B.A., Pyatkova A. P., Miroshnikova A. P., Chernenko Z. I., 2021 deposition in each ore field and deposit. In their opinion, the subsequent processes of polymetamorphism significantly transformed the already formed primary structures and ores and created a unique "Altai" type of pyrite-polymetallic mineralization, which is comparable with such world analogues as "Cypriot", "Ural" and "Kuroko", and later - "Filizchayskiy", "Atasuiskiyo", "Mirgalimsayskiy", "Priargunskiy" and "Sadonskiy" [2, 3].

Geological and structural setting of the origin of ore-magmatic complexes. According to modern concepts, the Rudny Altai is an active continental margin of the Altai-Sayan fold area (Fig. 1). In the Middle Paleozoic, it was a mobile belt of the tectonosphere with a special deep architecture of structures under tectonic stresses directed from the north-east to south-west. This was established by gravimetry, magnetometry, seismology, seismic exploration, electrometry, and geothermy data.

A system of adjacent subparallel and obliquely intersecting deep faults falling to the northeast at $60-70^{\circ}$ angles was formed along the southwestern edge of the Altai microcontinent. They contributed to the formation of the Rudny Altai tectonic-magmatic lithosphere block, which is linearly elongated in the north-west direction between the Irtysh and North-East shear zone.

The intracontinental Irtysh rift zone functioned on the site of the Irtysh deep fault in the Silurian-Devonian. The Rudny Altai was located in the northeast of the rift zone and was a zone of sialic crust basification. The Ensialic island arc was formed here at the stage of zone closure in Famennian time; it was consolidated by the volcanic-sedimentary dacite-andesite formation of the Pikhtov suite $\left(\mathrm{D}_{3} \mathrm{fm}_{1}\right)[3]$.

The linear intracontinental Northeast rift was formed in the Beloubinsky-Sarymsaktinsky zone in the northeast of the riftogenic zone on the border with the Gorny Altai. Sulphide lead and zinc deposits (Nikitinskoye, South Altai group, and others) were formed here. Subsequent tectonic-magmatic processes in the Carboniferous and Permian time significantly complicated the riftogenic structures with the movement of individual blocks along sublatitudinal and northeastern faults and the injection of giant granitoid masses. The Rudno-Altai 


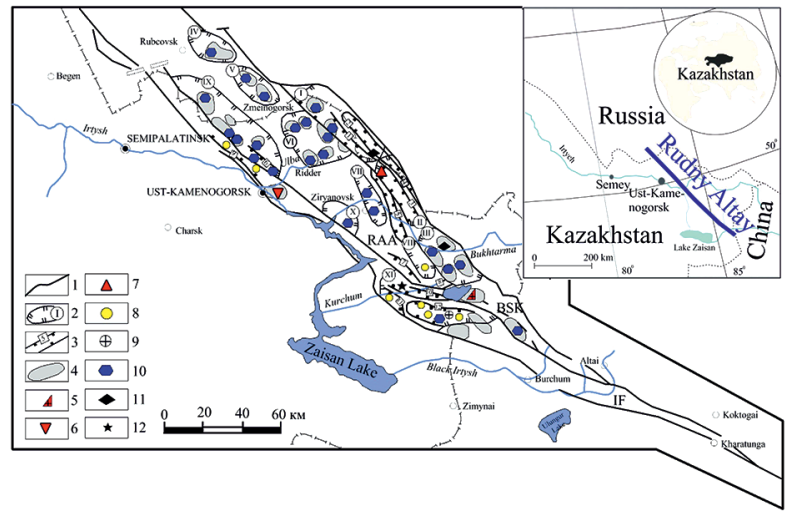

Fig. 1. Rudny Altaisky copper-polymetallic belt:

1 - boders of Rudny Altai belt; 2 - ore regions borders; 3 - Irtysh collapse zone; 4 - ore regions; 8-12-deposits: 8 - copper; 9 - copper-zink; 10 - pyrite-polymetallic; 11 - lead-zink; 12 zink-lead

metallogenic zone is characterized by a mosaic-block structure of riftogenic zones within which volcanic-tectonic uplifts were formed (Rubtsovskoye, Aleyskoye, Sinyushinskoye, Revnyushinskoye, and others). They were areas of intense manifestation of predominantly Middle Upper Devonian acidic (rhyolitic) volcanism [4].

Uplifts in deep fault zones bordered on volcanic-tectonic depressions which were filled with terrigenous rock mass, pyroclastic sediments, and volcanic formations of the basaltandesite-rhyolite formation $\left(\mathrm{D}_{2} \mathrm{gv}-\mathrm{D}_{3} \mathrm{fm}_{1}\right)$ (the Irtysh ore district) [5].

A stratiform hydrothermal-sedimentary mineralization was formed within the Leninogorsk depression simultaneously with volcanic-terrigenous sediments (Ridder-Sokolnoye deposit, and others). Hydrothermal-metasomatic type of pyrite-polymetallic and copper-zinc mineralization $(\mathrm{Cu}, \mathrm{Pb}, \mathrm{Zn}, \mathrm{Au}, \mathrm{Ag}$, etc.) is prevalent in the Irtysh depression (the Irtysh ore region). Deposits of this type do not extend beyond the limits of the contrast basalt-rhyolite formation $\left(\mathrm{D}_{1} \mathrm{e}-\mathrm{D}_{3} \mathrm{fr}\right)$ laterally and vertically (Tishinskoe, Maleevskoye, Artemyevskoye, and so on).

As seen, the main industrial pyritic deposits of the Rudny Altai were formed in a riftogenic geodynamic setting and, according to metallogenic zoning, are combined into a large Rudny Altai copper-polymetallic belt of regional significance, which is a part of the general geological structure of the Greater Altai [6, 7].

The ore belt in question is oriented in the north-western direction (its length is about $1000 \mathrm{~km}$ ); in the northwest it can be traced in Russia (Rubtsovsky, Zmeinogorsky and other ore regions). In the southeast its continuation is covered by the Maimyr downfold sedimentary mass of the Low Carbonic age. Then, the ore belt is identified in a reduced form in Southern Altai in the Markakol tectonic block (near Lake Markakol), where the Alexandrov-Terektinsky ore zone is located (Fig. 1).

Further, the ore belt is traced in China where industrial pyrite deposits of Ashaly, Koktal and Timurty are known.

A model of a polymetallic ore belt formation can be represented as follows. Poor ore - bearing volcanites of the daciteandesite formation $\mathrm{D}_{3} \mathrm{fm}_{2}$ (the Pikhtov suite) typical of island arcs were localized here at the end of the Famennian time. The subsequent oncoming movement of the Kazakhstan massif was accompanied by the convergence of microcontinent and blocks, island arcs, and then by their accretion and joint into a single continental formation [7].

The compression processes of shifting lithospheric blocks led to the formation of a longitudinal asthenospheric uplift (Fig. 2) in the upper mantle due to the upward movement of the asthenospheric substance mass and fluid flows

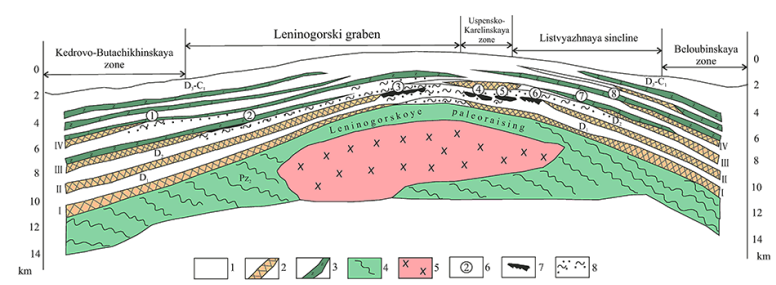

\section{Fig. 2. Model of Leninogorskoye ore area:}

1 - volcanogenic-sedimentary formations $\left(D_{1}-D_{3}\right)$ and carbonateterrigenous accumulations $\left(D_{3}-C_{1}\right) ; 2-$ sub- and interbedded bodies of porphyrite; 3 - tape-like bodies of porphyrite; 4 - green-slate formations of before-hercynian basis; 5 - granitoids of caledonian age; 6-7-pyrite-polymetallic deposits, ore zones and bodies, and theirs numbers (digits in circles): 1 - Gabriel, 2 - Tishinskoye, 3 - Ridder-Sokolnoye, 4 - Dolinnoye, 5 - Obruchevskoye, 6 Novo-Leninogorskoye, 7 - Shubinskoye, 8 - Starkovskoye; 8 gidrotermalit of scattered sulphidic mineralization

in deep faults. As a result, a complexly differentiated basaltandesite-rhyolite swarm of ore-bearing formations was formed [8].

The emerged ore-bearing volcanotectonic structures were significantly transformed and complicated along with ore bodies in later geodynamic situations (collisional compression, subvertical stretching, horizontal fault-shift displacements along tectonic zones).

The placement of giant ranges of magmatites and deep decompaction zones according to geophysical data collected by Lyubetskoy, G. P. Nakhtigal and other researchers allow us to assume the existence of local fluid-saturated systems with a complex differentiation of rock composition at depths of $80-100$ and $160-180 \mathrm{~km}$ in the past (according to F. A. Letnikov [9]).

In accordance with the idea of global geological processes cyclicity and the mantle-plume model of ore-magmatic system formation in general for Central Asia it can be assumed that the formation of pyrite deposits in the Rudny Altai is closely related to the impact of the mantle plume in the Devonian riftogenic geodynamic situation.

The accumulation of fluids and the concentrated migration of ore-saturated streams seems to be the main one for the potential productivity of the entire ore-forming system of the Rudny Altai; the presence of favorable structural elements facilitated the formation of fluid-magmatic complexes with zonal placement of ore-bearing elements (P.V.Yermolov, Ye. V. Ponomareva, V. S. Portnov, 2018) [10].

Deposits formed in the result, areas of scattered mineralization, zones of near-ore-altered rocks, vulcanites and subvolcanic porphyries and porphyrites are considered as a single Rudny-Altai copper-polymetallic ore-magmatic system (OMS).

Results. The main genetic types of the Rudny Altai pyritepolymetallic mineralization are distinguished according to their physical and chemical, geological and structural, mineralogical and geochemical peculiarities of ore formation.

The stratiform (hydrothermal-sedimentary) type includes pyrite-polymetallic mineralization, which lies among the sedimentary strata of the basalt-rhyolite formation. This group of ore objects is localized among unaltered or slightly altered sedimentary-pyroclastic and igneous rocks; it has lead, lead-zinc, gold-pyrite, and pyrite-polymetallic mineralization.

Ore bodies are characterized by the presence of weakly folded banded-layered, rhythmic and finely disseminated layered ores. Such ores were found in the $2^{\text {nd }}$ ore body of the Ridder-Sokolny deposit, Kalendarsky, Verkh-Ubinsky, Osenniy, Bannoye, Nikitinsky, Nikandrovsky, Pnevsky deposits and the South Altai group of ore occurrences (Fig. 3).

The hydrothermal metasomatic type of pyrite-polymetallic and copper-zinc mineralization is the most widespread and 


\begin{tabular}{|c|c|c|}
\hline Lithology & $\begin{array}{c}\text { Suite, } \\
\text { stage }\end{array}$ & Deposit \\
\cline { 1 - 2 } & \multirow{2}{*}{$\begin{array}{c}\text { Beloubinskaya } \\
\mathrm{D}_{2.3} \text { bl }\end{array}$} \\
\hline
\end{tabular}

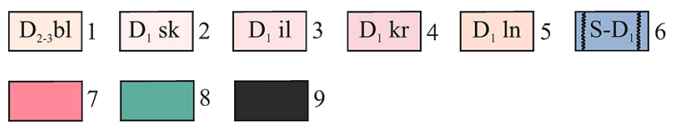

Fig. 3. Chronostratigraphic column showing the distribution of the deposits of the Leninogorskoye ore field:

1-Beloubinskaya suite; 2-Sokolnaya suite; 3 - Ilinskaya suite; 4 - Kryukovskaya suite; 5 - Leninogorskaya suite; 6-metamorphic rocks; 7 - veined-disseminated silver-barite-polymetallic ores; 8 streaky-disseminated polymetallic ores; 9 - sericitized clayey shales

the main one in the Rudny Altai. It is closely related to the riftogenic tectonic magmatic processes of the Hercynian cycle $\left(D_{2-3}\right)$ and the formation of subvolcanic porphyry bodies. The latter are accompanied by large areas of hydrothermal-metasomatic rocks (up to hydrothermalites and metasomatites) and pyrite mineralization in the form of separate ore bodies and deposits.

This type includes many porphyry-related industrial deposits. The latter occupy up to $40-80 \%$ of the volume of the Rudny Altai OMS and have a predominantly lapolite-shaped and subplastic form with their roots in the zones of magmabearing deep faults located along the periphery of large volcanic-tectonic uplifts (Fig. 3).

Hydrothermalites with pyrite-polymetallic mineralization are located in the frontal parts of ore-magmatic columns, in the areas of attenuation of porphyrites. The examples are large and unique deposits at the Rudny Altai (Orlovskoye, Zolotushinskoye, Artemyevskoye, Nikolaevskoe, Tishinskoe, Zyryanovskoye, Maleevskoye, Irtyshskoe and others); extensive geochemical oreols of concentration with a zonal distribution of ore-bearing elements $(\mathrm{Co}-\mathrm{Cu}, \mathrm{Cu}-\mathrm{Pb}-\mathrm{Zn}, \mathrm{Pb}-\mathrm{Ba}-\mathrm{Ag}, \mathrm{Au})$ are found here [11, 12].

As a rule, these areas are marked by a decrease in the intensity of the magnetic and gravitational fields, by high-intensity anomalous values of electric polarization, and so on. Sublayered and dyke-like bodies of porphyrites are widely developed. They are located both among and above porphyrites creating a screen for porphyrites and ore zones. The frontal parts of fluid-porphyry complexes have high prospects for identifying industrial pyrite-polymetallic mineralization [13].

The lithological control is characterized by belonging of deposit ore fields to compositionally contrasting packs of sedimentary and volcanogenic rocks of the rhyolite composition. Ten ore-bearing stratum levels stand out in the Rudny Altai. Mineralization at many deposits was found at several (from four to six) ore-bearing levels $D_{1-3}$. Only Early Givetian formations do not contain industrial mineralization [14].
Three main ore-bearing stratigraphic levels have been studied for the Russian part of the Rudny-Altai belt: EmsianEifelian (Zmeinogorsk deposit); Givetian (Zolotushinsky deposit); Frasnian (Rubtsovskoye and Talovskoye deposits).

For Kazakhstan deposits the most characteristic are Emsian-Eiffelian level (Ridder-Sokolnoye, Leninogorskoye); Early Eifelian (Zyryanovskoe); Late Eifelian (Maleevsky); Late Givetian (Nikolaev, Artemyevsky). Ore deposits can be located simultaneously at several stratigraphic levels.

Metamorphism of ores is common in the Rudny Altai. This made it possible to single out a special "Altaic" type of pyrite-polymetallic mineralization. Small relicts of primary ores with a specific anomalous mineral temperature zonality are found in the most metamorphosed deposits (Volkov, et al., 1972; Vorob'ev, 1963; Kalugin, 1981).

New ore bodies and zones of disseminated interspersed mineralization (often with reverse geochemical zonality) arose from the primary ore deposits under various post-ore metamorphic processes. Separate ore deposits and zones of Talovsky, Starkovsky, Verkh-Ubinsky, Orlovsky-Openyshevsky, Zyryanovsky, Novo-Berezovsky, Irtyshsky, Careyerny, Grekhovsky, Aleksandrovsky, Talovo-Turgusunsky, Zarya deposits and others can be attributed to them.

Many deposits contain a characteristic combination of hydrothermal-sedimentary and hydrothermal-metasomatic stages of ore formation. These stages can be separated by magmatic processes or structural rearrangement. Multi-stage metamorphism was caused by the Saurian phase of folding and intrusions (of the Zmeinogorsk complex and the Kalbinsk type granites $\left(\mathrm{P}_{1}\right)[1,8]$.

Based on the variety of mechanisms of formation of $\mathrm{Cu}$ polymetallic deposits, the duration of the manifestation of ore formation processes with subsequent transformations and transformations of ore objects, it is advisable to systematize extensive geological prospecting materials concerning the genetic features of the formation of structures and the placement of gold-color-metal ore in them, and on this basis to give a predictive assessment of deep-lying objects.

Mineralogical studies on copper-polymetallic deposit ores in the Rudny Altai were carried out by many geologists (B. I. Veits, I. V. Pokrovskaya, G. P. Bolgov, Kh. A. Bespayev, G. D. Ganzhenko, and others). Polyphase inclusions in minerals, isotopes of sulfur, lead, oxygen, and so on, pyritepolymetallic mineralization of Rubtsovsk, Zmeinogorsk, Priyrtyshsky, Leninogorsk and Zyryanovsk areas were considered (analyzed) by V.V.Avdonin, V. M. Chekalin, G. F. Yakovlev, A. S. Lapukhov, K. R. Kovalev, I. V. Gaskov, V. V. Popov, N. I. Stuchevsky, Yu. I. Dyomin, O. A. Kovrigo and many other researchers.

Parilov Yu. S. considered geological conditions of formation and possible sources of ore material of non-ferrous metal deposits in Kazakhstan based on the study on fluid inclusions [7].

Based on the analysis of available materials, it was established that the mineral composition of most deposits is rather uniform: galena, chalcopyrite, sphalerite, pyrite and gold. There are also fahlores, melnikovit-pyrite, pyrrhotite, magnetite, numerous minerals of silver, tellurium and other elements.

Our studies with a scanning electron microscope revealed a typomorphic paragenesis of ore minerals: chalcopyrite, sphalerite, galena, bismuthine, and aikinite $\left(\mathrm{CuFeBiS}_{3}\right)$ (Fig. 4, a). The size of microinclusions varies from the first units to 100 microns. The latest generation galena penetrates the chalcopyrite and sphalerite grains (Figs. $4, b-f$ ), and also forms small inclusions in pyrite and other minerals.

The finest inclusions of bismuthine $\left(\mathrm{Bi}_{2} \mathrm{~S}_{3}\right)($ Fig. $4, d)$ as well as impurities of (in wt\%): Ta (3.10), W (2.17), Se (6.78), $\mathrm{Ba}(1.95)$ and finely dispersed silver were found in galena. Aikinite forms vein impregnation in chalcopyrite (Fig. 4,e). Barite and calcite are observed among non-metallic minerals. 


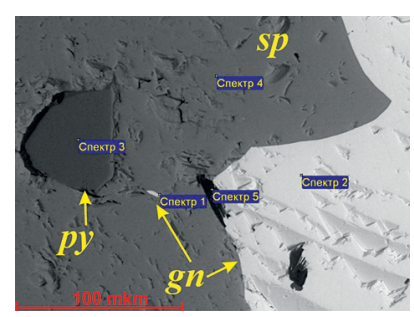

$a$

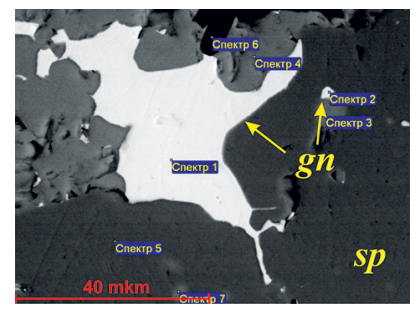

$c$

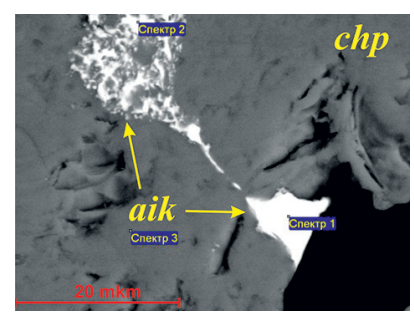

$e$

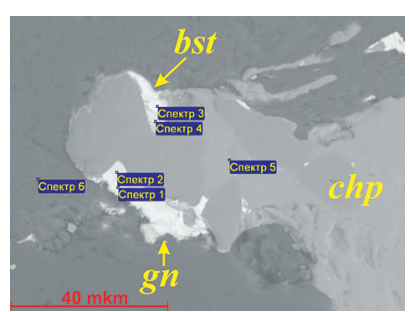

$b$

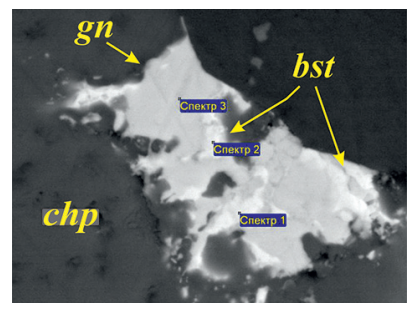

$d$

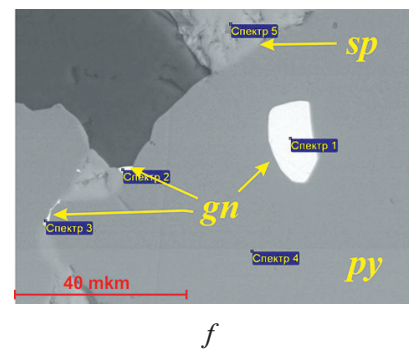

Fig. 4. Micro inclusions of minerals into pyrite polymetallic ores:

$a$ - typical association of galenite and pyrite (py); $b$ - joints of $a$ galenite (gn) and vismutin (bst) in a regional part with chalcopyrite $(\mathrm{chp}) ; \mathrm{c}$ - galenite micrograin in sphalerite (sp); $d$ - microinclusion of a galenite with parts of a vismutin and impurity Ta, W; evein inclusions of aikinite (aik) in chalcopyrite; $f$-microinclusion of a galenite $(\mathrm{gn})$ in pyrite

Such constancy of ore material composition suggests a similar source of ore material, the proximity of genetic types of deposits and the similarity of the composition of ore-forming solutions and fluid flows.

According to the above information, the process of ore formation in the Rudny-Altai deposits can be represented as follows. Ore-bearing fluids contained a wide range of ore elements ( $\mathrm{Cu}, \mathrm{Pb}, \mathrm{Zn}, \mathrm{Fe}, \mathrm{S}, \mathrm{As}, \mathrm{Au}, \mathrm{Bi}, \mathrm{Te}$, and so on), lithogenic elements ( $\mathrm{Si}, \mathrm{Mg}, \mathrm{Ca}, \mathrm{K}$, and so on), and dissolved gases $\left(\mathrm{CO}_{2}, \mathrm{~N}_{2}, \mathrm{H}_{2} \mathrm{~S}, \mathrm{SO}_{2}, \mathrm{~S}, \mathrm{HCl}, \mathrm{F}, \mathrm{Cl}, \mathrm{H}, \mathrm{H}_{2} \mathrm{O}\right)$. It was found that the main causes of ore deposition are the imbalance in the fluid system with decreasing pressure, temperature, acidity and composition.

Stratiform type of ores was formed from cold-water carbonic, sulfuric and ferrous solutions as a result of mixing them with sea waters enriched with ore elements, at a temperature of less than $100{ }^{\circ} \mathrm{C}$ and a pressure of $100-600$ bar. Ions of $\mathrm{Na}^{+}$, $\mathrm{Ca}^{++}, \mathrm{K}^{+}, \mathrm{HCO}_{3}^{-}$, and gases $\mathrm{CO}_{2}, \mathrm{H}_{2}, \mathrm{~S}$, and so on were detected in the ore-forming solutions based on the data of aqueous extracts.

It appears that the ore deposition mechanism is as follows. These solutions with an initial temperature of about $300{ }^{\circ} \mathrm{C}$ cooled and reacted actively with the sea water during pulsating inflow to the seabed under conditions of sharp changes in RT, Eh, and $\mathrm{pH}$ of the medium. This led to the formation of sedimentary hydrothermal layered ores. The sea water played an important role of a physical-chemical barrier for ore-bearing solutions. Siliceous, carbonate, and organogenic sediments with dispersed mineralization concurrently formed.
Variations in the isotopic composition of sulfur in sulfides are found in these ores, which indicates the presence of biogenic sulfur genesis along with juvenile sulphur. Thus, the pyrites of the $2^{\text {nd }}$ Ridder deposit contain $\delta^{34} \mathrm{~S}$ from -4.5 to $+14 \%$, at Kozlushinsky ore deposit $- \pm 10.1 \%$, and at Gabriel deposit $-+5 \%$. Sulfur of biogenic origin is found in pyrites of host rocks at Strezhansky, Tishinsky and Shemonaikha deposits.

In most deposits, sulfur composition is close to the meteorite level $\left(\delta^{34} \mathrm{~S}\right.$ is only +1.5 to $+5 \%$ ) . The amount of the $\delta^{34} \mathrm{~S}$ isotope increased with the ore process evolution in sulfides. All this indicates a single deep source of sulfur at all types of deposits and the genetic relation of ores.

Hydrothermal metasomatic ores were formed by the same primary solutions, but with less influence of sea water and increased changes in oxygen and sulfur regime as well as higher PT conditions. The bulk of sulphides were formed at a temperature of $200-350{ }^{\circ} \mathrm{C}$ and a pressure of 300 1500 bar. According to pyrite-chalcopyrite geothermometer data, the temperatures of various ore types formation were determined as $180-450{ }^{\circ} \mathrm{C}$ for copper-pyrite stockworks, 133-195 ${ }^{\circ} \mathrm{C}$ for tabular pyrite-polymetallic ores, 120$165{ }^{\circ} \mathrm{C}$ for densely impregnated copper-zinc ores, 100 $170{ }^{\circ} \mathrm{C}$ for polymetallic ores, $155-285{ }^{\circ} \mathrm{C}$ for barite-polymetallic ores. The isotopic composition of sulfur in sulfides is close to meteoric composition, it varies within a narrow range of values $\left(\delta^{34} \mathrm{~S}\right.$ from -4.2 to $+5.2 \%$, from 2.2 to $+2.0 \%$ on average) $[14,15]$.

The ores at the Rudny Altai deposits are complex in textural and structural peculiarities and mineral composition. They have increased concentrations of impurity elements (bismuth, tellurium, gold, silver, antimony, and so on) in the form of submicroscopic inclusions in fahlore, galena, chalcopyrite, and sphalerite. The content of these elements increases regularly from the early to late parageneses. The depth of primary ores formation is estimated from $0.2-0.5$ to $1.5-3 \mathrm{~km}$.

The data presented recreate the general picture of ore formation with an ascending pulsating vadose-hydrothermal system of solutions saturated with juvenile products $(\mathrm{Cu}, \mathrm{Pb}, \mathrm{Zn}$, $\mathrm{Fe}, \mathrm{S}, \mathrm{Ag}, \mathrm{Au}, \mathrm{Bi}, \mathrm{Se}, \mathrm{Te}, \mathrm{Pt}$, etc.) and leaching elements $(\mathrm{Ca}$, $\mathrm{Mg}, \mathrm{Si}, \mathrm{K}$, etc.) in unstable thermodynamic and physical and chemical conditions. In our opinion, the main deposits of the Rudny Altai cannot be considered polygenic since the mineralization was formed by a single source of ore matter generated by a common ore-bearing fluid system [10].

Conclusions. The Rudny Altai has been thoroughly studied by geological surveying and geophysical methods. Its ore fields and deposits have been estimated by numerous wells and underground mines. The depths of the wells reach $300-500 \mathrm{~m}$, in some places $700-1200 \mathrm{~m}$, there are separate wells with a depth of up to $2000 \mathrm{~m}$. Modern and restored structural and morphological models of ore fields and deposits of the Rudny Altai were considered by G. F. Yakovlev, G. N. Shcherba, A. A. Malygin, G.P. Nachtigall, H.A. Bespaev, N. V. Polyansky, G.D.Ganzhenko, V. M. Chekalin and other researchers (P. V. Yermolov, Ye. V. Ponomareva, V. S. Portnov, 2018) [14]. The pyrite-polymetallic and copper-zinc deposits formed in the Hercynian cycle of tectogenesis on the activated continental margin of the Rudny Altai and were controlled by a system of deep faults in the north-western direction.

According to the geotectonic position, they formed in a riftogenic geodynamic environment $\left(\mathrm{D}_{1} \mathrm{e}-\mathrm{D}_{3} \mathrm{fr}\right)$ and are genetically related to the group of basalt-rhyolite formations (differentiated and contrasting series) which display the results of the crust-mantle plume magmatism.

The model of ore formation reflects the genetic connection of pyrite deposits with the Devonian volcanism, a multistage ore process and a multi-storey distribution of gold-copper-polymetallic mineralization at various geochronological levels of the Devonian volcanic-sedimentary section (with a vertical span of ores up to $1000-1500 \mathrm{~m}$ ). 
Ore formation occurred under submarine conditions probably in an upward vadose-hydrothermal solution system with a juvenile source of metals ( $\mathrm{Fe}, \mathrm{Mn}, \mathrm{Cu}, \mathrm{Pb}, \mathrm{Zn}, \mathrm{Au}, \mathrm{Ag}$, and others) and dissolved gases $\left(\mathrm{CO}_{2}, \mathrm{~N}_{2}, \mathrm{H}_{2} \mathrm{~S}, \mathrm{~S}, \mathrm{Cl}\right.$, and others). Two ore types are distinguished by origin: stratiform hydrothermal-sedimentary type and hydrothermal-metasomatic type which are represented by the majority of pyrite-polymetallic deposits with rich complex ores $(\mathrm{Cu}, \mathrm{Pb}, \mathrm{Zn}, \mathrm{Au}, \mathrm{Ag}, \mathrm{Pt}$, and others).

As a result of paleometallogenic reconstructions, a peculiar Rudny-Altaic riftogenic copper-polymetallic OMS of the Devonian age productive for pyrite-polymetallic mineralization $(\mathrm{Cu}, \mathrm{Pb}, \mathrm{Zn}, \mathrm{Au}$, and so on) is distinguished.

The tendency of the belt distribution of pyrite deposits and the formation of a large Rudny-Altai copper-polymetallic belt of regional rank (length of about $1000 \mathrm{~km}$ ) was revealed. It shows its high energy potential and opens up new possibilities for prognosis and searching for hidden ore objects.

To implement the prognoses set forth in [16] and other papers a new stage of deep geological study on the Rudny Altai territory and promising ore-bearing structures is recommended. It is necessary to introduce modern methods for deep geological and mineralogical mapping of the main ore regions using modern technologies of geophysical and geochemical work, a significant scope of structural and exploratory drilling, and the widespread introduction of high-precision analytical research.

Acknowledgment: the authors express their gratitude to Nachtigall G. P. for the materials provided to them on the topic of the article. This work was supported by the Science Committee of the Ministry of Education and Science of the Republic of Kazakhstan, grant AP08856325, BR10264558.

\section{References.}

1. Kozlov, M. S. (2015). Formation conditions of the Rudny Altai metallogenic province. Geology of Ore Deposits, 57(4), 266-291.

2. Dergachev, A. L., Eremin, N. I., \& Sergeeva, N. E. (2011). Volcanogenic pyrite deposits of the Besshi type. Bulletin of the Moscow University, 4(4), 53-60.

3. Lobanov, K., Yakubchuk, A., \& Creaser, R.A. (2014). Besshi type VMS deposits of the Rugny Altai (Central Asia). Economic Geology, 109, 1403-1430.

4. Yakubchuk, A., Degtyarev, K., Maslennikov, V., Wurst, A., Stekhin, A., \& Lobanov, K. (2012). Tectonomagmatic settings, architecture and metallogeny of the Central Asian copper province. Society of Economic Geology Special Publication, 16, 403-432.

5. Kuzmin, M. N., \& Yarmolyuk, V. V. (2017). Biography of the Earth: the main stages of geological history. Nature, 6, 12-25. 6. Kuybida, M. L., Kruk, N. N., Shokalskiy, S. P., Gusev, N. I., \& Murzin, O.V. (2015). Subduction plagiogranites of Rudny Altai: age and composition characteristics. Doklady Earth Sciences, 464(1), 914-918.

7. Parilov, Yu. S. (2012). Genesis of the main types of non-ferrous metals deposits in Kazakhstan (based on the results of studying fluid inclusions). Almaty. Retrieved from http://nblib.library. kz/elib/Sait/\% D0\%A2\%D1\%80\%D1\%83\%D0\%B4\%D1\% 8B\%20\% D1\%83\% D1\%87\% D0\% B5\%D0\%BD\%D1\%8B \%D1\%85\%20\% D0\%9A\%D0\%B0\%D0\%B7/geolog/3\%20 Parilov\%20Genezis\%20mestorojdenie.pdf.

8. Malygin, A.A., \& Nachtigal, G.P. (1999). Restoration of ore-magmatic systems as a method of forecasting industrial pyrite-polymetallic deposits of the Rudny Altai. Geology of Kazakhstan, (2), 29-42.

9. Letnikov, F. A. (2001). Ultradeep Fluid Systems of the Earth and Problems of Ore Genesis. Geology of Ore Deposits, 43(4), 291-307.

10. Bach, W., Jöns, N., \& Klein, F. (2013). Metasomatism within the ocean crust. In: Harlov, D.E., \& Austrheim, H.
Metasomatism and the Chemical Transformation of Rock, (pp. 253-288). Berlin-Heidelberg: Springer.

11. Ganzhenko, G. D., Yudovskaya, M.A., \& Vikentiev, I. V. (2018). Gold-polymetallic mineralization of the Ridder-Sokolny deposit in Rudny Altai (Eastern Kazakhstan), Mineralogy, 4(1), 8-31.

12. Mizernaya, M., Miroshnikova, A., Pytkova, A., \& Akylbaeva, A. (2019). Main geological-industrial types of gold deposits in East Kazakhstan, Naukovyi Visnyk Natsionalnoho Hirnychoho Universytetu, (5), 5-11 https://doi.org/10.29202/ nvngu/2019-5/2.

13. Zinoviev, S. V. (2016). The role of dynamometamorphism in the formation of ore deposits (on the example of the Pyrite from Tishinsky and Ridder-Sokolny deposits of Rudny Altai). Geology and geophysics, 57(3), 521-536.

14. Mizernaya, M., Dyachkov, B., Kusmina, O., Mizerny, A., \& Oitseva, T. (2017). Main types of gold deposits of the eastern Kazakhstan. International Multidisciplinary Scientific GeoConference Surveying Geology and Mining Ecology Management, SGEM, 17(11), 299-306. https://doi.org/10.5593/ sgem $2017 / 11 / \mathrm{S} 01.038$

15. Yarmolyuk, V.V., \& Kuzmin, M. I. (2012). Late Paleozoic and Early Mesozoic rare-metal magmatism of Central Asia: Stages, provinces, and formation settings. Geology of Ore Deposits, 54(5), 313-333.

16. Innovative and promising technologies of geological exploration in Kazakhstan: Proceedings of the International Scientific and Practical Conference. Almaty. (2017).

\section{Провідні генетичні типи колчеданно- поліметалічних родовищ Рудного Алтаю}

\section{М. О. Мізерна ${ }^{1}$, Б. О. Д’ячков ${ }^{1}$, А. П. Пяткова ${ }^{1}$ А. П. Мірошнікова ${ }^{2}$, 3. I. Черненко}

1 - Східно-Казахстанський технічний університет імені Д. Серікбаєва, м. Усть-Каменогорськ, Республіка Казахстан, e-mail: mizernaya58@bk.ru

2 - Філія РГП «НЦ КПМС РК» «ВНИИцветмет», м. Усть-Каменогорськ, Республіка Казахстан

Мета. Вивчення процесів, що сприяють формуванню колчеданно-поліметалічного зруденіння на Рудному Алтаї, розробка рекомендацій напрямів подальших досліджень

Методика. Аналіз літературних і фондових матеріалів, польові дослідження в межах відомих рудних полів і родовищ, випробування та проведення лабораторних досліджень: спектральний аналіз, дослідження хімічного складу порід, що вміщають (ISP-MS - Agilent 7500сx), вивчення мінерального складу основних типів зруденіння (JSM 6390LV) .

Результати. Побудована модель колчеданно-поліметалічного зруденіння генетично пов'язаного із девонським базальт-андезит-ріолітовим раннєгерцінським рифтогенним вулканізмом $\left(\mathrm{D}_{1} \mathrm{e}-\mathrm{D}_{3} \mathrm{fr}\right)$.

Наукова новина. Підкреслюється просторова приуроченість ряду промислових родовищ, ареалів сульфідної мінералізації та околорудно-гідротермально змінених порід до областей виклинювання між- і субпластових субвулканічних порфірів середнього - верхнього девону та порфіритів, шо їх перекривають, які створюють своєрідні рудно-магматичні системи (РМС).

Практична значимість. Рекомендується новий етап глибинного геологічного вивчення території Рудного Алтаю та перспективних рудоносних структур із впровадженням сучасних методів глибинного геологічного й мінерагенічного картування.

Ключові слова: генезис, колчеданно-поліметалічні руди, порфіри, рудно-магматичні системи, Рудний Алтай 


\section{Ведущие генетические типы колчеданно- полиметаллических месторождений Рудного Алтая}

\section{М. А. Мизерная ${ }^{1}$, Б. А. Дьячков ${ }^{1}$, А. П. Пяткова ${ }^{1}$, А. П. Мирошникова ${ }^{2}$, З. И. Черненко ${ }^{1}$}

1 - Восточно-Казахстанский государственный технический университет имени Д. Серикбаева, г. УстьКаменогорск, Республика Казахстан, e-mail: mizernaya58@ $\underline{\text { bk.ru }}$

2 - Филиал РГП «НЦ КПМС РК» «ВНИИцветмет», г. Усть-Каменогорск, Республика Казахстан

Цель. Изучение процессов, способствующих формированию колчеданно-полиметаллического оруденения на Рудном Алтае, разработка рекомендаций направлений дальнейших исследований

Методика. Анализ литературных и фондовых материалов, полевые исследования в пределах известных рудных полей и месторождений, опробование и проведение лабораторных исследований: спектральный анализ, исследование химического состава вмещающих пород (ISP-MS - Agilent 7500сx), изучение минераль- ного состава основных типов оруденения (JSM 6390LV).

Результаты. Построена модель колчеданно-полиметаллического оруденения генетически связанного с девонским базальт-андезит-риолитовым раннегерцинским рифтогенным вулканизмом $\left(\mathrm{D}_{1} \mathrm{e}-\mathrm{D}_{3} \mathrm{fr}\right)$.

Научная новизна. Подчеркивается пространственная приуроченность ряда промышленных месторождений, ареалов сульфидной минерализации и околорудно-гидротермально измененных пород к областям выклинивания меж- и субпластовых субвулканических порфиров среднего - верхнего девона и перекрывающих их порфиритов, создающих своеобразные рудно-магматические системы (РМС).

Практическая значимость. Рекомендуется новый этап глубинного геологического изучения территории Рудного Алтая и перспективных рудоносных структур с внедрением современных методов глубинного геологического и минерагенического картирования.

Ключевые слова: генезис, колчеданно-полиметаллические руды, порфиры, рудно-магматические системы, Рудный Алтай

Recommended for publication by Ye. M. Sapargaliyev, Doctor of Geological and Mineralogical Sciences. The manuscript was submitted 03.12.20. 